\title{
BIOLOGICAL CHARACTERS OF FELTIELLA ACARISUGA \\ (VALLOT) (DIPTERA: CECIDOMYIIDAE) WHEN FED ON \\ EGGS OF TETRANYCHUS URTICAE KOCH \\ [ACARI: TETRANYCHIDAE]
}

GHADA S. REFAEI and AZZA A. MOHAMED

Plant Protection Research Institute, ARC, Dokki, Giza

(Manuscript received 25 March 2012)

\begin{abstract}
This study was carried out to estimate the different biological characters and predation capacity of $F$. acarisuga when feed on Tetranychus urticae Koch (Acari: Tetranychidae) eggs. The mean duration of developmental stages of $F$. acarisuga was averaged $13.5 \pm 2.6$ at $25 \pm 2{ }^{\circ} \mathrm{C}$ and $60-75 \%$ R.H. On the other hand, Preovipostion, Oviposition and post oviposition periods revealed an average $2.9 \pm 3.9,6.2 \pm 5.2 \& 6.9 \pm 4.3$, respectively. Female longevity was recorded of $15.2 \pm 4.0$ days and Fecundity was attained $34.9 \pm 6.1$ at the experimental conditions with daily rate reached $3.7 \pm 1.9$. The total number of eggs of $T$. urticae consumed by the larval stages $\left(1^{\text {st }}, 2^{\text {nd }}\right.$, and $\left.3^{\text {rd }}\right)$ of, $F$. acarisuga were $21.9 \pm 1.5,47.1 \pm 2.8$ and $55.5 \pm 2.9$ eggs, respectively.
\end{abstract}

\section{INTRODUCTION}

The tetranychid mite, Tetranychus urticae Koch (Acari: Tetranychidae) is one of the most important pests of different crops around the world. Studies of yield reduction caused by varying population levels of $T$. urticae have demonstrated its potential for damaging the different crops (Oatman et al., 1982; Raworth, 1986). Pesticides are the primary method of control of $T$. urticae. A major problem in controlling this spider mite is its ability to develop rapid resistance to acaricides after only few applications. To reduce pesticide input and associated risks and costs, biological control of spider mites is widely used worldwide (Mo and Liu 2006).

The predator Feltiella acarisuga (Vallot) (Diptera: Cecidomyiidae), is considered one of the most important and widely distributed natural enemies of spider mites (Tetranychidae) (Gagne 1995).

F. acarisuga became an important component of the biological control of $T$. urticae and could be particularly useful for integrated pest management (Gillespie et al., 1998). F. acarisuga adults are capable of flying and tracking colonies of T. urticae. In addition to its excellent flying capacity, distributing $F$. acarisuga in the crop requires very little work. F. acarisuga larvae fed on eggs, nymphs and adults of red spider mites at least 5 times many (per day) as Phytoseiulus persimilus (Acari: phytoseiidae) (Osborne et al. 2008). 


\section{MATERIALS AND METHODS}

\section{Feltiella acarisuga rearing}

Biological characters of $F$. acarisuga when fed on $T$. urticae eggs was estimated under laboratory condition at $25 \pm 2{ }^{\circ} \mathrm{C}$ and $60-75 \%$ R.H. Larvae and pupae of $F$. acarisuga were received from infested bean leaflets, and stored in transparent plastic container until adults hatch. Each couple of $F$. acarisuga was allowed to mate and oviposit in class tube $(3 \times 5 \mathrm{~cm})$ covered with muslin and provided daily with $T$ urticae eggs as a prey. Leaves contained $F$. acarisuga eggs were kept separately until larvae hatch.

The newly hatched larvae were kept singly in small Petri dishes $(5 \mathrm{~cm})$ on their beans leaflets and provided daily with two spotted spider mite eggs until pupation. As the cecidomyiid pupa was formed, it was removed and confined individually in transparent plastic containers $(2 \times 5 \mathrm{~cm})$ until adult emergence. At least, 20 replicates were evaluated on each temperature. The duration of immature development, feeding capacity of the larvae and female fecundity were estimated daily.

One female and two males of $F$. acarisuga were placed per tube, males were removed $48 \mathrm{hr}$ after the female had emerged. The number of eggs laid per female was monitored daily.

\section{Rearing of Tetranychus urticae}

A mass culture of the two-spotted mite $T$. urticae was maintained on potted bean plants under the same laboratory conditions to prepare an adequate food source for $F$. acarisuga.

\section{RESULTS AND DISCUSSION}

\section{Egg stage, Larval and pupal periods}

Results showed that the incubation period was averaged $1.4 \pm 1.5$ days under laboratory condition at $25 \pm 2{ }^{\circ} \mathrm{C}$ and $60-75 \%$ R.H. While, the duration of the different larval stages fed on $T$. urticae eggs lasted $1.8 \pm 1.2$ for the first larval instars, $2.3 \pm 2.42$ days for second instars and $1.9 \pm 2.2$ days for the third instars (table 1 ). The pupal stage period lasted $6.1 \pm 3.4$ days. This result is found close that obtained by with Agamy and Gomaa (2002).

\section{Total developmental periods}

Data indicated that the total developmental duration was found to be $13.5 \pm 2.6$ days (table, 1). In contradictory, several authors found that, F. acarisuga completed its life cycle in 29 days (Sharaf 1984), in 16.4 days (Mo and Liu, 2006) and in 17.4 days (Mo and Liu, 2007).These differences in developmental times are likely 
dependent on temperature and/or relative humidity differences (Opit, et al., 1997; Gillespie and Raworth 1999).

\section{2- Female development and Fecundity}

Table (2) showed that maximum female longevity was15.2 days, while female fecundity was attained to be $34.9 \pm 6.1$ eggs per female under the same laboratory conditions with a daily number of eggs $3.7 \pm 1.9$ I per female. The sex ratio was rounded off to $1: 1$, these results are in agreement with these of Gillespie et al. (1997), Agamy, and Gomaa (2002)

\section{3- Predating capacity $\boldsymbol{F}$. acarisuga.}

The average number of consumed eggs by $F$. acarisuga $1^{\text {st }}, 2^{\text {nd }}$, and $3^{\text {rd }}$ instar larvae was $21.9 \pm 1.5,47.1 \pm 2.8$ and $55.5 \pm 2.9$ eggs, respectively. Therefore, the total number of eggs of $T$. urticae consumed by the three larval instars was recorded as $124.5 \pm 4.2$ (Table 3 ). Similarly, larva of $F$. acarisuga could consume an average of 175.4 T. cinnabarinus eggs (Mo and Liu, 2006). Gillespie et al. (2000) studied life table parameters of $F$. acarisuga using the carmine spider mite, Tetranychus cinnabarinus eggs as prey under laboratory conditions of $26.7 \pm 2{ }^{\circ} \mathrm{C}, 75 \pm 5 \%$ R.H. The first, second, and third instars larvae of $F$. acarisuga consumed an average of 35.5, 54.0 and 86.9 T. cinnabarinus eggs, respectively.

From the above results, it could be concluded that the predator $F$. acarisuga predator appeared to have highly specialized abilities feeding on spider mite eggs and could be particularly useful for biological control.

Table 1. Mean duration (in days) of the female developmental stages of the predator Feltiella acarisuga when fed on Tetranychus urticae eggs under laboratory conditions.

\begin{tabular}{|c|c|c|}
\hline \multicolumn{2}{|c|}{ STAGE } & DURATION \\
\hline \multirow{3}{*}{ LARVA } & EGG & $1.4 \pm 1.5$ \\
\cline { 2 - 3 } & $1^{\text {ST }}$ INSTAR & $1.8 \pm 1.2$ \\
\cline { 2 - 3 } & $2^{\text {ND }}$ INSTAR & $2.3 \pm 2.4$ \\
\cline { 2 - 3 } & $3^{\text {RD }}$ INSTAR & $1.9 \pm 2.2$ \\
\hline \multicolumn{2}{|c|}{ PUPAL STAGE } & $6.1 \pm 3.4$ \\
\hline MEAN DURATION OF DEVELOPMENT & $13.5 \pm 2.6$ \\
\hline
\end{tabular}


Table 2. Mean duration (in days), longevity and fecundity of the predator Feltiella acarisuga when fed on Tetranychus urticae eggs under laboratory conditions.

\begin{tabular}{|c|c|}
\hline STAGE & DURATION \\
\hline PREOVIPOSTION & $2.9 \pm 3.9$ \\
\hline OVIPOSTION & $6.2 \pm 5.2$ \\
\hline POSTOVIPOSTION & $6.9 \pm 4.3$ \\
\hline LONGEVITY & $15.2 \pm 4.0$ \\
\hline FECUDITY & $34.9 \pm 6.1$ \\
\hline DAILY EGGS/FEMALE & $3.7 \pm 1.9$ \\
\hline
\end{tabular}

Table 3. Rates of consumed Tetranychus urticae eggs (per day) by larval instars of the predator Feltiella acarisuga.

\begin{tabular}{|c|c|}
\hline & \\
\hline LARVAL INSTARS & DURATIONS \\
& \\
\hline $1^{\text {ST }}$ INSTAR & $21.9 \pm 1.5$ \\
\hline $2^{\text {ND }}$ INSTAR & $47.1 \pm 2.8$ \\
\hline $3^{\text {RD }}$ INSTAR & $55.5 \pm 2.9$ \\
\hline TOTAL & $124.5 \pm 4.2$ \\
\hline
\end{tabular}

\section{REFERENCES}

1. Agamy, E. A. and W. O. Gomaa. 2002. Biological studies and food consumption on Feltiella acarisuga (Vallot) (Diptera: Cecidomyiidae) a predator of the spider mite, Tetranychus urticae Koch (Acari: Tetranychidae). Egyptian J. Biol. Pest Control 12. $87-89$.

2. Gagne R. J. 1995. Revision of tetranychidae (Acarina) mite predators of the genus Feltiella (Diptera: Cecidomyiidae). Ann. Entom. Soc. of Amer. 88: 16-30.

3. Gillespie, D. R., D. J. M. Quiring, and M. Greenwood. 1997. Collection and selection of natural enemies of twospotted spider mites for biological control. J. Entomol. Soc. Br. Columbia 94. 7-11. 
4. Gillespie, D. R., B. Roitberg, E. Basalyga, M. Johnstone, G. Opit, J. Rodgers, and N. Sawyer. 1998. Biology and application of Feltiella acarisuga (Vallot) (Diptera: Cecidomyiidae) for biological control of two spotted spider mites on greenhouse vegetable crops. Pacific Agri-Food Res. Center Tech. Report No. 145: 1-4. Agriculture \& Agri-Food Canada. Agassiz, BC, Canada.

5. Gillespie, D. R., G. Opit, and B. Roitberg. 2000. Effects of temperature and relative humidity on development, reproduction and predation in Feltiella acarisuga (Vallot) (Diptera: Cecidomyiidae). Biol. Control 17. 132-138.

6. Gillespie D. R and D. A. Raworth (1999): Biological control of two spotted spider mites on greenhouse Vegetable Crops. Agriculture and Agri-Food Canada. P. 3032.

7. Mo, T. L. and T. X. Liu. 2006. Biology, life table and predation of Feltiella acarisuga (Diptera: Cecidomyiidae) feeding on Tetranychus cinnabarinus eggs (Acari: Tetranychidae). Biological control. 39, 418-426.

8. Mo, T. L. and T. X. Liu. 2007. Predation and life table of Feltiella acarisuga (Diptera:Cecidomyiidae) preying on eggs of Tetranychus urticae (Acari: Tetranychidae). Environ. Entomol. 36(2):369-75.

9. Oatman, E.R., Sances, F.V., LaPr'e, L.F., Toscano, N.C. and Voth, V. 1982. Effects of different infestation levels of the two-spotted spider mite on strawberry yield in winter plantings in southern California. J. Econ. Entomol. 75: 94-96.

10. Opit G. P., B. Roitberg and D. R. Gillespie. 1997. The functional response and prey preference of Feltiella acarisuga (Vallot) (Diptera: Cecidomiidae) for two of its prey: male and female two spotted spider mites, Tetranychus urticae Koch (Acari: Tetranychiidae). Can. Entomol. 129: 221-227.

11. Osborne R.O., N. C. Leppla and L. S. Osborne. 2008. Predatory gall midge (unofficial common name), Feltiella acarisuga (Vallot) (Insecta: Diptera: Cecidomyiidae).

12. Raworth, D.A. 1986. An economic threshold function for the two-spotted spider mite, Tetranychus urticae (Acari: Tetranychidae) on strawberries. Can. Entomol. 118: 9-16.

13. Sharaf, N. S. 1984. Studies on natural enemies of tetranychid mites infesting eggplant in the Jordan Valley. J. Appl. Entomol. 98. 527-533. 


\section{Feltiella acarisuga (VALLOT) الصفات البيولوجيه للمفترس}

عند تغذيتة على بيض العنكبوت الأحمر العادى

$$
\text { غادة رفاعي و عزة عبد الجواد }
$$

$$
\text { معهُ بحوث وقاية النباتات- مركز البحوث الزرراعية - الدقي - الجبزة- مصر. }
$$

إجر اء بعض الدر اسات البيولوجية للمفترس Feltiella acarisuga عند درجة حرارة 2 土 25 م م ورطوبة نسبية 60-70 \% لمعرفة دورة حياتة عند تغذيتة على بيض العنكبوت الأحمر العادى كأحد عناصر المكافحة الحيوية.

أوضحت نتائج الصفات البيولوجية لهذا المفترس ان فترة العمر غير الكاملة (البيض، اليرقة

و عذر اء) قد سجلت 13.5 يوم بينما وجد أن فترة ما قبل وضع البيض رفترة وضنت وضع البيض وفثرة

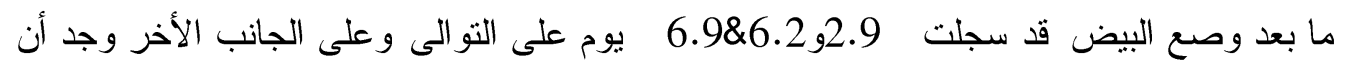

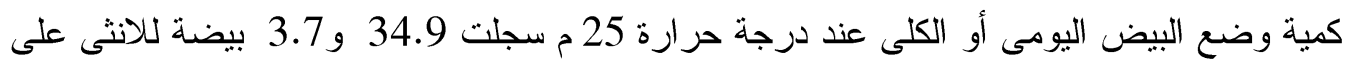

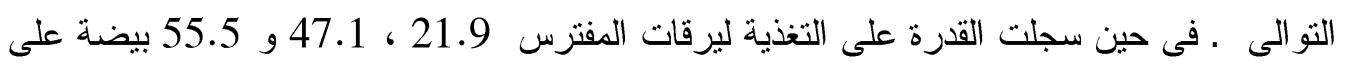
التو الى. 